\title{
El consumo de la utopía romántica. El amor y las contradicciones culturales del capitalismo, de Eva Illouz
}

\author{
Nataly Guzmán Velasco \\ Universidad Centroamericana \\ "José Simeón Cañas", UCA
}

Por más de 100 años, la industria publicitaria nos ha dicho cómo debemos lucir para convertirnos en objeto de deseo, ser amados, recibir invitaciones a círculos sociales determinados y captar todas las miradas. Esta presentación de fórmulas de atractivo personal se expandió a lo largo del siglo XX en medios impresos, afiches y carteles. Con la llegada del cine, la radio, la fotografía y la televisión se establecen nuevos ideales estéticos de belleza y gallardía, y nuevos espacios de diversión y cortejo. En este contexto, los productos, las prácticas de consumo y los ámbitos que se ofrecen para alcanzar el romance no se promo- cionan como simples mercancías, sino como dispositivos que permiten adoptar determinados estilos de vida. En su libro El consumo de la utopía romántica: El amor y las contradicciones culturales del capitalismo, la socióloga israelí Eva Illouz explica de forma sencilla pero muy detallada que los medios masivos no se inventaron el amor, pero que sí lo materializaron en una utopía visual de ensueños y de felicidad garantizada a partir del consumo de determinados productos. Los medios le ponen un rostro de características muy específicas al romance y establecen las vías de llegada hacia un mundo de ideales y promesas de realización. 
En este libro, Illouz presenta ideas clave para discutir cómo el mercado se apropia del tema del romance, de qué manera lo conceptualiza, a través de qué representaciones le da un rostro gráfico y cómo la experiencia romántica se convierte en una práctica cultural y económica de consumo masivo. El texto muestra también un estudio que busca identificar qué aspectos de las vivencias románticas de los sujetos en la vida cotidiana están determinados por las imágenes y los mensajes que describen el amor de pareja en los anuncios de las revistas, las escenas cinematográficas o la música popular. Desde esta perspectiva, me parece que el trabajo de Illouz ofrece un aporte muy importante para construir una mirada multidisciplinar de los vínculos entre la cultura y el consumo a partir de la sociología, la filosofía, la economía, la psicología y la comunicación. Esto sin contar con que el libro también analiza la visión de género con la que se edifican las representaciones de lo que deben ser el hombre y la mujer que quieran conformar una pareja ideal en el contexto posindustrial.

La autora plantea que el amor romántico es la ideología que camina de la mano con el capitalismo industrial, a lo largo de su ascenso, y que esto permite la promoción y la apropiación de formas de comportamiento romántico que se consideraron como novedosas a inicios del siglo XX. Hasta entonces, las relaciones de cortejo entre las parejas se daban al interior del espacio privado de los hogares familiares, donde los hombres solteros visitaban a las hijas de familia con la intención de formar una posible alianza formal. La tradición era una rígida supervisión de la pareja y el objetivo era el matrimonio. Por ello, de acuerdo con Illouz, una de las primeras transformaciones de la temática amorosa que se introduce con el capitalismo tardío es que el amor no encierra un valor final en sí mismo, sino que es una herramienta para la búsqueda de una felicidad más de tono individual pero sin dejar el concepto de pareja. Es muy interesante ver cómo Illouz documenta el proceso de construcción del mercado del amor que se crea a través de la cultura del ocio y de la romantización de los artículos de consumo, así como la penetración de una serie de referentes en torno al romance que siguen vigentes hasta la fecha.

Este libro da muchas pistas para indagar sobre la manera en que la publicidad y los medios en general configuraron un vínculo entre el romance y el mercado al transformar el sentido del amor 
en una dinámica para experimentar sentimientos intensos, aventuras, diversión y fantasía a través de diferentes actividades de consumo fuera del hogar: salones de baile, restaurantes, parques de diversiones y clubes nocturnos. $Y$ aunque esta investigación se centra en el rostro que le dan al amor los medios masivos tradicionales, es un estudio útil también, a partir de las categorías de análisis que proporciona Illouz, para analizar la manera cómo hoy día las personas construyen en las redes sociales sus propias narrativas sobre el romance, sus concepciones de género, su ideología en torno a la pareja y la familia, sus representaciones sobre el amor y los símbolos con los que asocian este sentimiento.

Eva Illouz explica que la relación entre la industria del ocio y el consumo masivo asociado al romance se consolidó a partir del impulso que se le da a la novedad de tener una cita romántica en un espacio público, lejos del ojo vigilante de los jefes del hogar. La autora deja claro que es muy difícil establecer de qué manera los medios transforman la cultura y las relaciones sociales, pero que sí se puede determinar qué tipo de ideales de felicidad, promovidos por los medios, materializan visualmente el romance perfecto $y$ robustecen determinados elementos del capitalismo industrial a partir de imágenes aspiracionales de belleza, glamour, elegancia, distinción y seducción. El texto de Illouz también ilustra con mucho detalle de qué manera los medios intervienen en la construcción de la identidad de los sujetos "modernos", a partir de la industria de la moda, el mercado de la cosmética, la posibilidad de adquirir un automóvil y la disponibilidad de la tecnología.

Además, la autora plantea cuál es la visión de la sociología marxista sobre la sociedad posindustrial, las dinámicas de consumo, el comportamiento del consumidor que busca el amor y la fetichización del romance por medio de unos artículos que al mismo tiempo que muestran su disponibilidad a partir del mercado intentan invisibilizar el escenario económico que los produce. Illouz aporta interesantes puntos de partida para discutir cómo se modifican las dinámicas de consumo a partir de estrategias mediáticas que le atribuyen vida propia a determinados productos, de manera que no sólo prometen mantener viva la llama del amor, sino que incluso tienen el poder de arreglar relaciones que ya estaban cayendo en el aburrimiento: los productos son descritos por los medios y la publicidad como dispositivos para mantener la 
emoción de la pasión en la pareja. Desde estos puntos parte la segunda porción del título de este libro: El amor y las contradicciones culturales del capitalismo.

A pesar de que la autora toma como modelo de su estudio a la sociedad estadounidense, es importante destacar que la mayoría de los puntos que señala en torno a cómo operan las industrias que promueven el consumo masivo son bastante comunes con la manera en que se vive la relación del sujeto con el consumo de la utopía romántica en nuestras regiones. De ahí que una de las cualidades más importantes de este libro es que no sólo plantea un panorama detallado de posibilidades sobre cómo abordar un estudio sobre la relación entre la cultura, el consumo, la identidad y las representaciones utópicas del romance que han prevalecido por mucho tiempo, sino que también toca el tema de las contradicciones y las ambigüedades que generan los vínculos de todos estos elementos. Entre algunas de las que menciona la autora, a continuación se destacan cuatro de ellas.

En primer lugar, la ambigüedad de la promesa mediática del amor eterno, puesto que una vez establecido el vínculo amoroso de la pareja es necesario continuar consumiendo para no perderlo. No es tan importante el encontrar el amor de nuestra vida, como el consumir los productos correctos para conservarlo. En segundo lugar, el llamado publicitario se hace a un sujeto con capacidad adquisitiva, al mismo tiempo que se le solicita que se olvide del trabajo para poder concentrarse en disfrutar del consumo que éste le permite. En tercer lugar, los medios y la publicidad promocionan un amor espontáneo, auténtico e incondicional, al mismo tiempo que establecen unas reglas definidas para determinar si el amor es verdadero a través del consumo de los productos correctos y de las actividades de ocio señaladas como ideales. Y, en cuarto lugar, el mercado promueve la democracia del consumo, en el sentido que cualquiera podría tener la posibilidad de consumir pero en una categoría coherente con su clase social y su capacidad adquisitiva. Illouz destaca, a partir de este último punto, que el mercado de los consumos románticos y de las citas tiene también una categoría para clasificar a un sujeto cuando éste gasta más allá de sus posibilidades: si se extralimita, ha sido bajo el concepto de la "ocasión especial".

Para identificar cómo viven los sujetos estas invitaciones 
al consumo, en qué medida se apropian de los referentes del romance publicitario o cinematográfico y cómo describen sus propias experiencias amorosas, Eva Illouz también presenta en este texto un estudio que realizó a partir de entrevistas con un número representativo de personas y con la respectiva metodología que construyó para realizarlo. Resulta interesante, como describe la autora, que los participantes hacen referencia al hecho de que están al tanto de las fantasías románticas que presentan los medios dentro de sus narrativas pero, con todo y eso, al mismo tiempo describen sus experiencias románticas personales a través de representaciones ligadas a los referentes que promueven los medios. Este texto es un aporte muy importante para el estudio de la relación que existe entre la cultura y las prácticas de consumo. Illouz documenta con rigor las ideas de diferentes autores en torno al tema y establece con mucha claridad qué criterios de análisis se pueden tener en cuenta para elaborar una investigación multidisciplinar a partir de narrativas mediáticas que continúan marcando de manera significativa la identidad, las emociones y los imaginarios colectivos con implicaciones sociales que van más allá del mercado.

\section{Referencias bibliográficas}

- Illouz, E. (2009). El consumo de la utopía romántica. El amor y las contradicciones culturales del capitalismo. Buenos Aires, Argentina: Katz Editores. 